KIRJA-ARVIOITA

\title{
Aikuisopinnot, maaseutu ja viestintä muutoksen kourissa
}

\section{Seppo Niemelä:}

1. Suomen ehdot. Sisun ja sivistyksen ohjelmaluonnos. Gummerus 1992 (107 s).

2. Maaseudun merkitys. MSL 1994 (55 s). 3. Aikuisopinnot ja vapaa sivistystyö. MSL. 1995 (34 s).

\section{Muutoskirja. Rohkaisuksi murroksen maailmaan. Kunnallisen kehittämissäätiön Polemia-sarja nro 12. Gummerus 1995 (87 s).}

Maaseudun Sivistysliiton toiminnanjohtaja Seppo Niemelä on vaikuttaja, joka osaa siirtää yhden elämänpiirinsä kokemukset toiseen ja välittämään näin muodostuvan synteesin muiden käytettäväksi kolmannessa yhteydessä.

Niemelä tunnetaan historialtaan ja taustaltaan lähinnä aikuiskasvatuksen, maaseudun ja viestinnän puolestapuhujana. Nyt hän on ahkeroinut lyhyessä ajassa kokoon neljä näitä alueita käsittelevää teosta, jotka tukevat (ja toistavatkin) toinen toistaan.

Varsinkin uusimmissa kirjoissa näkyy selvästi kaksi juurta: Niemelän liikenneministeriölle laatima viestintäpoliittinen selvitys ja toisaalta yhteispohjoismainen monivuotinen elinikäisen oppimisen aivoriihi (lopputuote Guldtavlorna i gräset, NMR, Nord 1995:3).

Seppo Niemelä kirjoittaa paljon lukeneen ja historiansa tuntevan pohdittua, tiivistä (joskus liiankin tiivistä) ja samalla paikoin hyvinkin nautittavaa tekstiä. Perusteellisin ja helppolukuisin teoksista on vanhin, Suomen ehdot, lukijaltaan vaativin Muutoskirja.

Nykyistä muutosvauhtia kuvaa, että 1992 julkaistua Suomen ehdot -kirjaa voi jo nyt lukea osittain yhtä jälkiviisaana kuin viime viikon sääennustuksia. "Suomen ehdoissa" selvitellään, miten tähän on tultu ja millä tästä selvittäisiin (Selviämisstrategia kiteytettynä: Pitkäkuituinen havupuu ja koulutettu ihminen!)

Suomen ehdot on kirjoitettu laman syvimmässä shokissa. Sitä leimaa vielä hämmentynyt invalidius iskukykymme menetyksestä ja suomalaisuuden hiipumisesta. Hammasta kiristellään: miksi Pohjolan Japani löikään lainiin laman ennusmerkit. Uhkakuvilla herkutellaan: "Nälkiintyneet ihmismassat repivät viimeisenkin vihreän maasta." Sen sijaan esim. ay-liike leimataan vain laimeasti "ajan vaatimuksista jälkeenjääneeksi". Kirjoitushetkellä ei vielä ollut näyttöä, miten tehokkaasti ay-liike voi ja kehtaa jarruttaa lamasta toipumista.

Kirjan parasta antia on mielestäni terävä sivistysanalyysi. Miksi todellakin poliittisessa keskustelussamme jokainen erimielisyyden ilmaus muistuttaa vastustajan henkistä teloitusyritystä?

Yliopistojen ja tutkimuksen kritiikki erityisesti niiden Ulkopuolelta on aina paikallaan. Harjoitettu kasvatustiede ei Niemelän mukaan pysty tarttumaan perusasioihin. Väite on mielenkiintoinen, mutta jää keskeneräiseksi. jäämme odottamaan kirjoittajan ennakoimaa yliopistojen kohtaamaa arvostelun aaltoa. Ensimmäiset laineet ovat jo lyöneet.

Maaseudun merkitys on perusvireeltään jo aivan toisenlainen. Sen tehtävänä on valaa uskoa maaseudun tulevaisuuteen - mitenkäs muuten Maaseudun Sivistysliiton toiminnanjohtaja. Kirjassa käydään kursoorisesti 
läpi maaseudun aineellinen ja henkinen kehitys. Siitä käy hyvin ilmi, miten erilainen koko maaseutu-käsite Suomessa siihen olennaisesti liittyvine metsineen on kuin useimmissa EU-maissa.

Maaseudun ihmis- ja itsekäsitys kaikkine samanaikaisine ristiriitaisine rooleineen olisi todella mielenkiintoinen tutkimusala. Niemelä käy kiihkottomasti läpi faktat, joista muutokset maataloudessa ja sitä kautta koko maaseudulla johtuvat, miksi ei enää selvitä entisillä eväillä. On varmasti vapauttavaa monen umpikujaan ajautuneen maatalouden harjoittajan lukea, ettei kysymys todellakaan ole siitä, että hän omaa taitamattomuuttaan on haaskannut isäinsä perinnön.

Nieminen näkee maaseudun mielestäni liiankin talonpoikaisesta näkökulmasta. Ei kuitenkaan ole vain yhtä ammattiryhmää koskeva ongelma, että juuri valmistuneen selvityksen mukaan Suomi, nimenomaan Väli-Suomi, autioituu 150 neliökilometrin vuosivauhdilla. Siinä ei auta enää edes maausko uus. Ongelma on yhteinen.

Aikuisopinnot ja vapaa sivistystyö on monille alkuiskasvattajille suurelta osin erilaisista muista yhteyksistä tuttua tekstiä. Kirjaan on kerätty yhteen aikuiskasvatuksen tämän hetken ongelmat, haasteet, mahdollisuudet ja ratkaisumallit. Julkaisuntarkoitukseksi ilmoitetaan avoimesti vaikuttaminen koulutusta koskevan lainsäädännön uudistamiseen. Siitä voi arvata, että kirjassa korostetaan aikuiskasvatuksen ja vapaan sivistystyön omaleimaisuutta ja muusta koulutuksesta poikkeavan lainsäädännön tarpeellisuutta. Totta, mutta ei aikuiskasvattajille kovin uutta.

Tuore on kirjoittajan tiivis luku vapaasta sivistystyöstä, jonka tärkeimmäksi osaksi hän näkee ihmisen todellisuussuhteen kehittämisen. Siihen lukuun on mielestäni koottu uuden kansansivistyksen oikeutus ja tulevaisuuden tehtävä, jos demokratiassa silloin elämme.

Viestintäalan asiantuntijalta olisin toivonut, että oma mielitiettyni, monimuoto-opetus opastusjärjestelyineen olisi tullut tulevaisuudennäkymissä selvemmin esille. On kai todettava, että Suomi on auttamattomasti menettänyt tässä suhteessa käsillä olleen mahdollisuutensa olla tulevaisuuden lipunkantaja.

Joka tapauksessa "Aikuisopinnot ja vapaa sivistystyö asettaa perinteisen vapaan sivistystyön uudistuneena luontevaksi ja uskottavaksi koulutuksen, sivistyksen ja kasvatuksen tulevaisuuden osaksi.

Kun Niemelä vielä Suomen ehdoissa jää päivittelemään, miten tähän on tultu ja selvitäänköhän, niin "Muutoskirjassa" - siinä mä Seppona seison taas: Kirja on täynnä optimismia. Kaikki näyttää lupaavalta. Ihminen oppii oppimaan. Maaseudun asema paranee. Suomella on sisäistä voimaa selviytyäkseen. Maailma on täynnä mahdollisuuksia. Kirja on todella kirjoitettu alaotsikkonsa mukaisesti rohkaisuksi murroksen maailmaan. Ainoa todella suuri uhka on luonnon kosto sen hallitsijana itseään pitäville ihmisille.

Muutoskirjassa käydään osittain hengästyttävällä vauhdilla läpi maailman, valtion, yhteiskunnan ja yhteisöjen muuttuminen. Taustalla jää ilman vastausta soimaan virttynyt vinyyli: "Muuttuuko ihminen, ja mihin suuntaan..." Niemelää kiusaa, ettei hän löydä nykyiselle yhteiskuntamme kehitysvaiheelle sopivaa nimeä. Hän kaipaa toimintapoliittista keskustelua ja tutkimusta - aivan aiheellisesti.

Muutoskirja on tärkeä kirja. Paitsi, että se sopii jokaiselle tulevaisuusalustajalle ja puhujalle retoriikan lähteeksi, se on kiehtova pohja itse kunkin työn tulevaisuuden pohdinnalle. Tiivisteenä se toimii monen asiakokonaisuuden osalta valikkona, joka avaa omalle ajatukselle laajemmat vainiot. Niinkuin Niemelä sanoo, Suomessa on vaikea puhua, mutta helppo ajatella.

"Muutoskirjan" sanoma on, että ihmisen kyky, halu ja päätös oppia koko elämän ajan on tärkein turva jatkuvan murroksen maailmassa. 
Niemelän teosten tekstiä vaivaa suomalaisajattelijoiden perusvika: asiat esitetään useasti niin viimeisen päälle hiottuina kristallisoituina ketjunpäinä, että äkkinäisen lukijan on ajateltava ajatusketju takaperoisesti alkutekijöihinsä ymmärtääkseen sen. Eikä suinkaan aina voi olla varma, onko löydetty alkulähde oikea.

Kirjasarja on muutoksen pyörittelemille tervetullut kasvualusta, jolla voi saattaa kasvamaan omiakin tulevaisuudenkuviaan aikuiskasvatuksesta, maaseudusta ja yleensä kulttuurimme kehityksestä.

Olavi Alkio 